\title{
Author Correction: The disease resistance protein SNC1 represses the biogenesis of microRNAs and phased siRNAs
}

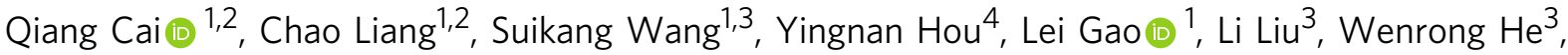 \\ Wenbo Ma ${ }^{4}{ }^{4}$, Beixin $\mathrm{Mo}^{1} \&$ Xuemei Chen ${ }^{3}$
}

Correction to: Nature Communications; https://doi.org/10.1038/s41467-018-07516-z; published online 29 November 2018.

The original version of this Article contained an error in the spelling of the author Beixin Mo, which was incorrectly given as Beixing Mo. This has now been corrected in both the PDF and HTML versions of the Article.

Published online: 04 February 2019

\begin{abstract}
(c) (i) Open Access This article is licensed under a Creative Commons Attribution 4.0 International License, which permits use, sharing, adaptation, distribution and reproduction in any medium or format, as long as you give appropriate credit to the original author(s) and the source, provide a link to the Creative Commons license, and indicate if changes were made. The images or other third party material in this article are included in the article's Creative Commons license, unless indicated otherwise in a credit line to the material. If material is not included in the article's Creative Commons license and your intended use is not permitted by statutory regulation or exceeds the permitted use, you will need to obtain permission directly from the copyright holder. To view a copy of this license, visit http://creativecommons.org/licenses/by/4.0/.
\end{abstract}

(c) The Author(s) 2019

\footnotetext{
${ }^{1}$ Guangdong Provincial Key Laboratory for Plant Epigenetics, College of Life Sciences and Oceanography, Shenzhen University, Shenzhen 518060, China.

${ }^{2}$ Key Laboratory of Optoelectronic Devices and Systems of Ministry of Education and Guangdong Province, College of Optoelectronic Engineering, Shenzhen University, Shenzhen 518060, China. ${ }^{3}$ Department of Botany and Plant Sciences, Institute of Integrative Genome Biology, University of California, Riverside, CA 92521, USA. ${ }^{4}$ Department of Microbiology and Plant Pathology, University of California, Riverside, CA 92521, USA. These authors contributed equally: Qiang Cai, Chao Liang.. Correspondence and requests for materials should be addressed to B.M. (email: bmo@szu.edu.cn)

or to X.C. (email: xuemei.chen@ucr.edu)
} 